\title{
Le cheval dans le monde romain
}

Martial Monteil

\section{OpenEdition}

\section{Journals}

Édition électronique

URL : http://journals.openedition.org/rao/2800

DOI : 10.4000/rao.2800

ISBN : 978-2-7535-4053-8

ISSN : 1775-3732

Éditeur

Presses universitaires de Rennes

Édition imprimée

Date de publication : 15 décembre 2014

Pagination : 442

ISBN : 978-2-7535-4051-4

ISSN : 0767-709X

\section{Référence électronique}

Martial Monteil, «L Le cheval dans le monde romain », Revue archéologique de l'Ouest [En ligne], 31 | 2014

mis en ligne le 15 décembre 2014, consulté le 04 décembre 2020. URL : http://

journals.openedition.org/rao/2800; DOI : https://doi.org/10.4000/rao.2800 


\section{Cristina A. et Hincker V., 2014 - Le cheval dans le monde romain, Bayeux, OREP Éditions et conseil général du Calvados, 64 p. (ISBN 978-2-8151-0189-9, 10,20 €) 442}

Voici un petit livre "grand public", fort bien fait et entièrement consacré au cheval durant l'Antiquité romaine. Ses deux auteurs principaux sont, pour l'une, professeur certifié et en thèse sur l'élevage des chevaux durant l'Antiquité tardive (Amandine Cristina) et, pour l'autre, archéologue au service d'archéologie du conseil général du Calvados (Vincent Hincker). Ils se sont en outre associés à plusieurs spécialistes des sources archéologiques, archéozoologiques, textuelles et iconographiques, pour brosser un tableau le plus complet possible.

Les trois grandes parties qui composent l'ouvrage s'enchaînent logiquement. La première s'appuie sur les écrits des agronomes et des traités d'hippiatrie (médecine vétérinaire appliquée aux équidés) pour recenser les différentes races de chevaux connues dans l'Empire romain, avec leurs caractéristiques principales. On remarquera ici que les chevaux des Gaules romaines sont singulièrement absents des sources textuelles. L'élevage est ensuite abordé au travers de l'archéozoologie, qui témoigne d'une augmentation de la taille des chevaux en Gaule entre la fin de la protohistoire et le Haut-Empire, et diverses autres sources permettant d'évoquer les lieux d'élevage, la nourriture, la reproduction ou encore le dressage.

La deuxième partie traite des usages du cheval entre équipement, monte d'agrément, pratique de la chasse ou de la guerre, transport et, bien sûr, les fameuses courses dans les cirques. S'y ajoutent les utilisations secondaires comme la viande, qui n'est plus consommée à l'époque romaine alors qu'elle l'était par les Gaulois, ou encore l'emploi d'une partie des ossements pour la fabrication d'objets.

La troisième partie nous entraîne dans les domaines du symbolisme et de l'imaginaire, avec les chevaux associés à la gloire et au triomphe des généraux et des empereurs vainqueurs, et la relation qu'ils entretiennent avec les dieux, certaines figurations monstrueuses, tels les centaures, ou encore avec la mort et les rituels funéraires.

En bref, il ne manque rien à cet opuscule très didactique et enrichi par une belle iconographie, qui est à recommander à tous ceux qui ont toujours tout voulu savoir sur le cheval à l'époque romaine

Martial MonTeIL 